\title{
PHARMACIST COUNSELING EFFECT TO THE LEVEL OF PATIENT KNOWLEDGE WITH TYPE 2 DIABETES MELLITUS IN "KIMIA FARMA KAWI" PHARMACY, MALANG CITY
}

\author{
Abdul Hakim, Ria Ramadhani Dwi Atmaja, Hajar Sugihantoro, Fahda Dina Mufidah \\ Department of Pharmacy, Faculty of Medicine and Health Sciences, Universitas Islam Negeri Maulana \\ Malik Ibrahim Malang \\ Jl. Gajayana No 50 Malang \\ E-mail: \\ Ahrizfit@gmail.com \\ Ria.ramadhani85@yahoo.com \\ Fahdadina@gmail.com
}

\begin{abstract}
Diabetes mellitus is a carbohydrates, fats, protein metabolism disorder that caused by impaired insulin secretion, insulin disruption or both. Diabetes mellitus sufferer need a special care to make the blood glucose level always in normal condition and no complications in various organs. Type 2 diabetes mellitus is inception of disease begins with development of key metabolic abnormality, insulin resistance. Causes of type 2 diabetes mellitus is obesity, age over 40, lifesyle, genetic suscetibility. Pharmacist counseling to the patients of type 2 diabetes mellitus is very important because it can improve patient knowledge, patient compliance to the treatment and the quality of patients life. The purpose of this study is to determine the effect of counseling by pharmacists to the level of patient's knowledge of type 2 diabetes mellitus in "Kimia Farma Kawi" Pharmacy, Malang City.

This research is a quantitative study with Pre-Experimental design in the form of pretest - posttest design. Number of samples was taken during one month by using consecutive sampling method. The result of this study was using through Wilcoxon test that there was difference of value before and after the pharmacist counseling the patients of type 2 diabetes mellitus with significance value equal to $0.000 \mathrm{p}$ value $<0,05)$. The conclusion of this research is the pharmacist counseling can improve patient knowledge of type 2 diabetes mellitus.
\end{abstract}

Keywords : pharmacist counseling, knowledge, type 2 diabetes mellitus

J. Islamic Pharm., an open access journal ISSN : 2527-6123 


\section{INTRODUCTION}

Diabetes is a disease in which the patient suffers from insulin deficiency that causes the heap of glucose in the blood (hyperglycemia) or the decrease of cell receptor sensitivity to insulin (insulin resistance) caused by overeating and obesity [1]. There are two types of diabetes mellitus, type 1 and type 2 . The risk factors for diabetes are genetic, age $>45$ years, obesity and poor lifestyle [5].

Based on the data from Balitbangkes Kementrian Kesehatan 2014, diabetes mellitus is the third highest cause of death disease in Indonesia with the percentage 6.7\% [6]. One of the reasons of this high mortality rate is the patients' failure to control their blood glucose in long term caused by the lack of patients' knowledge about the disease and its treatments [2]. To help patients improve their knowledge of the disease and its treatments, counseling is given by the health personnel especially pharmacy.

The pharmacist's paradigm currently is not only on the drug oriented, but also the patient oriented. As the pharmacists' responsibility related to the patients' treatments to achieve the therapeutic results and improve the patients' life quality, so that the pharmaceutical care is done. One of the pharmaceutical care given by a pharmacist is counseling provision. Counseling is a two-way discussion between a pharmacist and a patient to solve the patient's problem in consuming their drugs or his illness [4]. Counseling provision is important to improve the patients' knowledge, compliance and glycemic control. This is in accordance with Surya research (2014) where the counseling provision influences the increased knowledge of the patients' diet with $5.59 \%$ chance of increasing knowledge [3].

One of the pharmacies that provides counseling service is Kimia Farma. According to the chief manager of Kimia Farma, diabetes patients mostly redeem their prescriptions in Kimia Farma Kawi Malang. This study was conducted to determine the influence of counseling by pharmacists to the knowledge level of patients with type 2 diabetes mellitus in Kimia Farma Kawi Malang.

\section{MATERIAL AND METHOD}

\section{Materials}

The population of this study was all the patients with type 2 diabetes mellitus who came to Kimia Farma Kawi Malang to redeem the diabetes drug by giving the prescriptions or the copy. While the sample in this study was in accordance with the inclusion and exclusion criteria research.

The tool used in this study was a questionnaire that contains questions about the name of diabetes drugs obtained, the reasons for using diabetes drugs, the function of diabetes treatment, how to consume, frequency, time and duration of diabetes drugs consumption, the knowledge of diabetes mellitus knowledge, normal glucose level and the characteristics of diabetes mellitus.

J. Islamic Pharm., an open access journal ISSN : 2527-6123 


\section{Method}

This research used pre-experimental of pretest-posttest design. The data were taken at Kimia Farma Kawi Pharmacy Malang in April 2017. The number of samples were taken based on the time that was during a month (april 2017) and taken by consecutive sampling method where all the subjects that came and fullfill the criteria included in the research.

The inclusion criteria in this study were patients with type 2 diabetes mellitus who redeemed their prescriptions or the copy in Kimia Farma Kawi Malang City, got counseling by pharmacist and were willing to participate in this research. While the exclusion criteria were type 2 diabetes mellitus patients who did not redeem their own drugs and used insulin.

Patients with type 2 diabetes mellitus who responded to the study were asked to fill out the questionnaires (pretest) before they received counseling by the pharmacist. Furthermore, counseling was given by the pharmacist. The pharmacist counseling was given by using dialogue methods and discussions as well as written information about the drugs obtained by respondents. After the counseling, then the respondents were asked to fill out the questionnaires (posttest). The data then were analyzed by using SPSS 23 program. To see the difference of mean value of variable on pretest and posttest, the wilcoxon test was used.

\section{RESULTS AND DISCUSSION}

\section{The Characteristics of Respondents}

The data were collected at Kimia Farma Kawi Malang. The number of respondents obtained during April2017 were 53 respondents. The characteristics of respondents in this study are shown in the table below.

a. Gender. The results showed that $54 \%$ of the respondents ( 29 respondents) were female and $45 \%$ (24 respondents) were male. According to the research conducted by the Ministry of Health and WHO (2010), that women are more vulnerable to health problems and the anxiety level is higher than men. In addition, women are more at risk of diabetes mellitus type 2 because physically women have greater risk of increased body mass index. According Dinas Kesehatan Kota Malang 2014, there are 43\% (13,643 women) included in the category of obesity, which became one of the risks of type 2 diabetes mellitus. And based on Riskedas 2007 result, the prevalence of type 2 diabetes in men of $4.9 \%$ and women $6.4 \%$ [6].

b. Age. The results showed that most of the respondents were 51-60 years old with the percentage $35 \%$ (19 people). According to the research, a person who attains the age $\geq 45$ years is more at risk of type 2 diabetes mellitus than those aged $<45$ years, this is due to body function decrease in metabolizing the body [7].

c. Duration of Type 2 diabetes mellitus. The result of this study showed that most of the respondents suffered type 2 diabetes mellitus during 1-5 years with the percentage $49 \%$ (26 people). The duration of suffering is related to the knowledge and compliance of patients taking the medicine.

J. Islamic Pharm., an open access journal ISSN : 2527-6123 


\section{Knowledge of Respondents}

The data were collected twice before and after the pharmacist gave the counseling. The results of the questionnaires can be seen in table 6 . Table 6 shows the different values before and after the counseling. It was proven by the results of the Wilcoxon analysis test where $\mathrm{p}$ Value $0.000<0.05$. And in accordance with the theory that the provision of counseling plays an important role to increase the knowledge which will be expected to change the attitude and behavior of a person with type 2 diabetes to adherence in therapy so as to improve the quality of life [8].

The Knowledge of diabetes medicine names. Although the pharmacist has explained it, the patients still have diverse knowledge, depending on how the patient absorbs the information obtained. The results showed that before the counseling, 45\% (24 respondents) answered correctly and after the counseling, the percentage increased to 94\% (50 respondents). The factor of the respondents' ignorance was the names because of their difficulty to memorize the name. Therefore, to avoid the wrong consumption of medicine. It is important to inform the respondents.

The reason for consuming diabetes medicine is to lower or control the blood glucose level [12]. Before the counseling was given by the pharmacists, $70 \%$ (37 respondents) answered correctly and after the counseling, the knowledge of respondents increased to $96 \%$ (51 respondents). The reason for consuming the medicine is important to be informed, since diabetes mellitus is a metabolic disorder disease that leads to various chronic complications. These chronic complications can be avoided or prevented by controlling the blood glucose levels [9].

The function of diabetes treatments is to relieve the symptoms, create and improve quality of life, prevent acute and chronic complications and reduce the rate of development of existing complications [10]. When the patient does not know the function of the medicine will affect its compliance, especially if the medicine used cannot give an effect directly and should be used in the long term, consequently the patient felt that the medicine did not give any effect. This is consistent with the theory that if the patient's need for treatment is not met then it may lead to the emergence of medicine related problems [11].

The way to consume diabetes medicines is by swallowing the medicines directly. Such as the consumption of sulfonylureas (glimepiride, gliclazid), where the intact medicine is swallowed and cannot be chewed. The dosage form is one of the factors that influence the process of medicine absorption in the gastrointestinal tract. Sulfonylurea has an effective absorption of gastrointestinal tract. Food and hyperglycemia situation can reduce this absorb. The therapy failure with any of the sulfonylurea derivation may also be caused by pharmacokinetic changes of the medicine, such as really fast destruction [1]. Therefore, the information of how to consume the medicine is important to reduce the occurrence of the medicine ineffectiveness.

Frequency of taking diabetes medication. The results showed before the counseling $63 \%$ (33 respondents) answered correctly and after the counseling, the knowledge of respondents increased to $92 \%$ (49 respondents). Oral diabetes medicines have different periods of action. In 
sulfonylurea, there are three action periods which are short acting, intermediate and long acting. Giving counseling about the frequency of taking diabetes medicine is important since consuming the medication should not be as their willing, or only consume the medicine when they remember, because each medicine has a different duration of action [13].

Time of consuming diabetes medication. The results showed that before the counseling was given, 66\% (35 respondents) answered correctly and after the counseling, the number increased to $91 \%$ (48 respondents). Diabetes medicine have different onset, peak and duration of action. There are diabetes medicines that must be consumed before meals, with meals and after meals. This will affect the effectiveness of the medicines themselves. For example, sulfonylurea I and II that should be consumed 15-30 minutes before meals because the medicine absorption occurs in the peptic system so that the presence of food will delay the drug absorbs [12].

Duration of diabetes treatment. The results showed that before given the counseling, $62 \%$ (33 respondents) answered correctly and after given the counseling by pharmacists, the number increased to $85 \%$ (45 respondents). The knowledge of treatment duration is important to inform. Diabetes mellitus is a chronic disease that requires treatment in the long term (long term therapy). The correct consumption of diabetes medication is routinely consuming the medicine every day and as recommended by the physicians [5].

The meaning of diabetes disease. The results showed that before the counseling was given, 66\% (35 respondents) answered correctly and after the counseling was given by the pharmacists, the number increased to $85 \%$ (45 respondents). Diabetes is a disease of excess blood glucose (hyperglycemia) caused by a deficiency of insulin or insulin resistance [14].

The knowledge of normal sugar level. The results showed that before the counseling 64\% (34 respondents) answered correctly and after the counseling was given, the number increased to $89 \%$ (47 respondents). The knowledge of normal blood sugar levels is important to be informed to the patients. When the patient knows the target of his blood sugar or blood glucose, it will reduce the risk of complications. According Lafata (2014), controlling fasting blood sugar levels regularly has a significant relationship to the patients' blood sugar levels. The more routine and on schedule the patient to control the fasting blood sugar levels, the level of sugar will be better.

Characteristics of diabetes. The results showed that before given the counseling, $72 \%$ (38 respondents) answered correctly and after given the counseling by pharmacists, the number increased to $92 \%$ (49 respondents). Diabetes mellitus is not a contagious disease, because the disease is not caused by a disease-causing germ or microorganism. The high red blood cells compared with white blood cells make the patient susceptible to germs and infections [15].

In addition to the significance value 0.000 in wilcoxon analysis, the effect of counseling by pharmacists can be seen in the ranks table (table 7). A total of 41 respondents included in the positive ranks group which means that the value after being given counseling by the pharmacist is greater than the value before being given counseling.

This increase of knowledge was caused by some factors. The counselors (pharmacists) have good skills and can build good communication with the counselees (respondents) in recognizing the disease. According to Tamsuri (2007), a counselor who has knowledge and skill J. Islamic Pharm., an open access journal ISSN : 2527-6123 
can help the counselee to know about himself at this time and possibly in the future, it is expected that the counselee can solve the problem and fill his own needs of the future.

In addition, communication is an important factor in the application of counseling, as Rochman (2010) explains that effective counseling uses good communication skills through asking, listening, giving direction and checking the counselee's understanding. In addition, the increase of knowledge is also influenced by the level of education of the respondents, in this study the level of education of most respondents is the level of college. This is in line with previous research which states that the higher education of the patients, then the better or faster they will receive and absorb the information from the counselor, and have a better way of thinking toward their disease and treatment. [16].

From the results of this research, counseling provision by pharmacists can influence the knowledge of type 2 diabetes mellitus patients. This increase will affect the patients' health status. In addition, the increased knowledge about diabetes mellitus can improve the patients' life quality and can prevent complications of diabetes mellitus.

Prevention of complications is an important thing to do so that the diseases such as heart disease, stroke, hypertension can be prevented, this also can reduce mortality rate. According to previous research conducted by Setyawati, Pusthika and Tjahjono (2013), it showed that counseling programs provided by pharmacists have a positive influence on glucose control and improve the patients' health behavior. The result of increased knowledge that occurs after the counseling was given by the pharmacist shows that the purpose of counseling is achieved. In accordance with the theory of education which states that counseling should aim to educate patients so that patients' knowledge about medicine will increase and this will encourage the behavior change. Through the counseling, the patient's assumptions and wrong behaviors will be corrected [4].

In this study, the counseling by pharmacists gave a big influence on the increase of respondents' knowledge. This is proven by the statistical results, respondents who experienced the increase is $77.3 \%$, respondents who did not experience the increase is $7.5 \%$ and the respondents who before and after the counseling answered the same answer is $15 \%$.

\section{CONCLUSION}

Based on the wilcoxon statistical result in this study, it can be concluded that there is an influence of counseling by pharmacists to the level of knowledge of type 2 diabetes mellitus patients in Kimia Farma Kawi Malang. This is proven by the statistical result of Wilcoxon test that obtained p-value of 0.000 which the value is smaller than 0.05 .

\section{REFERENCES}

[1] Suherman, Suharti K, 2011. Insulin dan Antidiabetik Oral dalam Farmakologi dan Terapi. Jakarta: Universitas Indonesia.

[2] Uddin.I, Ahmad Tj. Kurkuman RA, Iftikhar R. 2001. Diabetes Education: It's Effect On Glycemic Control. Annals of Saudi Medicine. 21; 1200-20. 
[3] Surya, Rita, dkk. 2014. Konseling Terhadap Peningkatan Pengetahuan Pasien Diabetes Mellitus Tipe 2. Jurnal Ilmu Keperawatan. ISSN: 2338-6371.

[4] Rantucci, M.J. 2009. Komunikasi Apoteker-Pasien. Jakarta: EGC.

[5] Departemen Kesehatan RI. 2005. Pharmaceutical Care Untuk Penyakit Diabetes Mellitus. Jakarta: Departemen Kesehatan RI.

[6] Balitbankes, 2014. Riset Kesehatan Dasar 2014, Laporan Nasional. Jakarta: Balitbangkes Depkes RI.

[7] Wicaksono, Radio Putro. 2011. Faktor-Faktor Yang Berhubungan Dengan Kejadian Diabetes Mellitus Tipe 2 (Studi Kasus Di Poliklinik Penyakit Dalam Rumah Sakit Dr. Kariadi Semarang). Semarang: Fakultas Kedokteran Universitas Diponegoro.

[8] Sukratini, Desak Putu, Wayan Ambartana. 2011. Pengaruh Konseling Gizi Terhadap Perubahan Kadar Gula Darah Berdasarkan Pengetahuan dan Kepatuhan Diet Penderita DM di Poliklinik Gizi RSUD Kabupaten Karangasem. Jurnal Ilmu Gizi, volume 2 nomor 2: 100-108.

[9] Karlsen et al. 2004. Effects of a Group-Based Counseling Program on Diabetes Related Stress, Coping, Psychological Well Being and Metabolic Control in Adults with Type 1 or Type 2 Diabetes, Patient Education and Counseling.

[10] Soegondo,S, dkk., 2009. Penatalaksanaan Diabetes Mellitus Terpadu. Jakarta: FKUI.

[11] Cipolle, R.J., Strand, L.M., Morley, P.C., 2004, Pharmaceutical Care Practice : The Clinician's Guide, $2^{\text {nd }} E d$., The McGraw-Hill Companies, Inc., New York : 1 - 5.

[12] Nita, Y., et al. 2012. Pengetahuan Pasien Tentang Diabetes dan Obat Antidiabetes Oral, Jurnal Farmasi Indonesia Vol. 6 No. 1:38-47.

[13] Raviglione M, Richard JO. Tuberculosis. In: Loscalzo, joseph, et al. Harisson's Pulmonary and Critical Medicine. New York: Mc Graw Hill Medical, 115-38.

[14] Tjay, Tan Hoan dan Kirana Rahardja. 2002. Obat-obat Penting. Jakarta: Gramedia.

[15] Marewa, Lukman Waris., et al., 2015. Kencing Manis (Diabetes Mellitus) di Sulawesi Selatan. Jakarta: Yayasan Pustaka Obor Indonesia.

[16] Ramadona, A. 2011. Pengaruh Konseling Obat Terhadap Kepatuhan Pasien Diabetes Mellitus Tipe 2 di Poliklinik Khusus RSU. Dr. M. Djamil Padang. Tesis. Universitas Andalas Padang.

J. Islamic Pharm., an open access journal ISSN : 2527-6123 
Table 1. Demographic Characteristics of Responden

\begin{tabular}{lcc}
\hline & $\mathbf{N}$ & $\%$ \\
\hline Gender & & \\
Male & 24 & 45 \\
Female & 29 & 45 \\
Age & & \\
$30-40$ & 3 & 5 \\
$41-50$ & 7 & 13 \\
$51-60$ & 19 & 35 \\
$61-70$ & 15 & 28 \\
$71-80$ & 9 & 16 \\
Duration of disease & & \\
$1-5$ mo & 12 & 22 \\
$6-12$ mo & 9 & 16 \\
$1-5$ y & 26 & 49 \\
$>5$ y & 6 & 11 \\
\hline
\end{tabular}

J. Islamic Pharm., an open access journal ISSN : 2527-6123 
Table 2. Comparison of Pre and Post Counseling Knowledge Scores

\begin{tabular}{lllll}
\hline \multirow{2}{*}{ Knowledge } & \multicolumn{3}{c}{ Pretest } & \multicolumn{2}{c}{ Posttest } \\
\cline { 2 - 6 } The knowledge of diabetes medicine names & 45 & 29 & 94 & $\mathrm{~F} \%$ \\
The reason for consuming diabetes medicine & 70 & 30 & 96 & 4 \\
The function of diabetes treatments & 49 & 51 & 77 & 23 \\
The way to consume diabetes medicine & 85 & 15 & 94 & 6 \\
Frekuency of taking diabetes medication & 63 & 37 & 92 & 8 \\
Time of consuming diabetes medicine & 66 & 34 & 91 & 9 \\
Duration of diabetes mellitus disease & 62 & 37 & 85 & 15 \\
The knowledge about the meaning of diabetes & 66 & 33 & 85 & 15 \\
disease & 64 & 36 & 89 & 11 \\
The knowledge about normal sugar level & 72 & 28 & 92 & 8 \\
Knowledge about characteristics of diabetes & 72 & \\
\hline
\end{tabular}

Table 3. Wilcoxon Statistics

Ranks

\begin{tabular}{|c|c|c|c|c|}
\hline & & $\mathrm{N}$ & $\begin{array}{l}\text { Mean } \\
\text { Rank }\end{array}$ & $\begin{array}{l}\text { Sum of } \\
\text { Ranks }\end{array}$ \\
\hline $\begin{array}{l}\text { Posttest - } \\
\text { Pretest }\end{array}$ & $\begin{array}{l}\text { Negative } \\
\text { Ranks } \\
\text { Positive } \\
\text { Ranks } \\
\text { Ties } \\
\text { Total }\end{array}$ & $\begin{array}{r}4^{a} \\
41^{b} \\
8^{c} \\
53\end{array}$ & $\begin{array}{l}15.13 \\
23.77\end{array}$ & $\begin{array}{r}60.50 \\
974.50\end{array}$ \\
\hline
\end{tabular}

a. Posttest < Pretest

b. Posttest $>$ Pretest

c. Posttest $=$ Pretest
Test Statistics ${ }^{\mathrm{a}}$

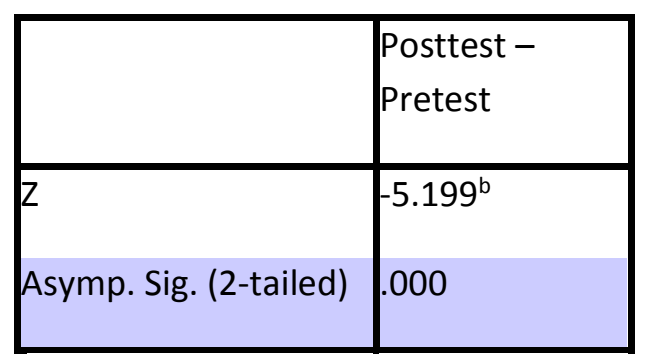

a. Wilcoxon Signed Ranks Test

b. Based on negative ranks.

J. Islamic Pharm., an open access journal ISSN : 2527-6123 